the mathematical treatment and in some of the assumptions made were pointed out, and it was concluded that these vitiated the correctness of the theory as a whole. Due to the lateness of the hour, a paper on "Mineralogy and Petrography of the Ordovician 'Metabentonites' and related Limestones", by C. E. Weaver and Dr. T. F. Bates (Pennsylvania State College), was read by title only.

This discussion left little doubt as to the importance of the contributions being made by clay mineralogists to geology, and especially to sedimentary petrology; but the general note was that the problems yet to be solved far exceed those to which present knowledge supplies an answer. A fitting conclusion, therefore, was the plea of Prof. Taylor that clay mineralogists should in all papers supply the fullest available geological data.

R. C. Mackenzie

${ }^{1}$ Millot, G., Geol. Appl. et Prospect. Minière, 2, Nos, 2, 3 and 4 (1949). ${ }^{2}$ Grim, R. E., Dietz, R. S., and Bradley, W. F., Bull. Geol. Soc. Amer. 60, $1785(1949)$

see Nagelschmidt, G., Imp. Bur. Soil Sci., Tech. Comm. No. 42, 2 (1944).

' Bowen, N. L., J. Geol., 30, 177 (1922); “The Evolution of Igneous Rocks", Chap, 5, 54 (1928).

s Wilkinson, P., Clay Min. Bull., No, 4, 122 (1950).

Mackenzie, R. C., Walker, G. F., and Hart, R., Min. Mag., 28, 704 (1949).

' See Nature, 168, 107 (1951).

\& Arens, P. I., Dissertation, Landbouwhogeschool, Wageningen (1951).

\section{FOOD PROTECTION IN THE UNITED STATES}

T

HE Delaney Committee established in 1950 by

the United States Congress is continuing its inquiry into the use of chemical additives in food processing and into the allied problem of the contamination of foodstuffs by residues from pesticides and detergents. The earlier sessions of this Committee $^{1}$ revealed that much of the experimental work on the toxicity of chemical additives had given results which were far from conclusive. Biochemists and physiologists in the universities and in foodmanufacturing concerns tended to adopt an extremely cautious attitude in their interpretation of these findings; other scientific workers adopted a somewhat different point of view. This division of opinion constituted a challenge to the objectivity of the scientific witness; a challenge which demanded action by an independent body able to discuss the difficult and complex problems in academic calm and with academic freedom.

Thus there came into being in 1951 a Food Protection Committee formed on the initiative of the Food and Nutrition Board of the National Research Council--itself established in 1916 as an offshoot of the National Academy of Sciences for the purpose of providing panels of independent advisers to the United States Government. This Council is representative of more than ninety major scientific societies and includes business men as well as scientific workers and technologists.

The Food Protection Committee has outlined its programme under four headings as follows. (1) It will assemble scientific information on both incidental and intentional chemical additives which are used, or proposed for use, in or on foods and will summarize and evaluate this information and make its conclusions available in usable form to those interested. (2) It will advise and assist industry and Federal and State government agencies in the integration of research on the utilization of chemicals in food production, processing and preservation, and will promote additional research, by existing agencies, which in the opinion of the Committee appears desirable in the public interest. The Committee itself, however, does not propose to conduct or finance research. (3) It will seek to develop guiding principles and standardized procedures essential for safeguarding food. (4) It will encourage and aid in the distribution of accurate scientific information to the general public.

Under the chairmanship of Prof. H. E. Longenecker, dean of the Graduate School of the University of Pittsburgh, the Committee consists of eleven men of science all holding academic appointments in different universities and in different fields-ranging from human pathology and nutrition, through biochemistry and pharmacology to entomology and plant pathology. Four groups have been established (each under the chairmanship of a member of the Committee) to deal with specific inquiries on the following respective subjects : toxicology, pesticides, food technology and chemistry. The groups are composed primarily of men of science in educational posts, with a lesser number drawn from research associations and other bodies. They are assisted by four advisory panels : from industry, from trade associations and research foundations, from government agencies, and from scientific and technical bodies. This relatively complicated structure is designed to ensure, on one hand, objectivity in decisions and, on the other, channels for the present. ation of divergent points of view and interests.

A recently published statement ${ }^{2}$ of the Food Protection Committee gives a broad survey of the problems under discussion and reveals the efforts being made to provide the equivalent of a pharmacopoeia listing the chemical additives in use and their biological effects on experimental animals and on man. This is a project which should prove of permanent value and might well be a fruitful field of international co-operation between scientific workers in Great Britain and their colleagues across the Atlantic.

'Aylward, F., Nature, 168, i48 (1951).

"Food Protection Committee, "Use of Chemical Additives in Foods" (Nat. Res. Council, 2101 Constitution Avenue, Washington 25, D.C., 1951).

\section{ORIGIN AND DISTRIBUTION OF CULTIVATED PLANTS IN SOUTH ASIA}

DLANT breeding in South Asia has in the past largely been limited to selection in local races, which have the great advantage of being closely adjusted by a long process of natural selection to local climatic conditions. Much more than this is now needed. It is necessary to make large collections of both wild and cultivated forms of economic plants, as well as of crossable wild species in the genus. The species itself, and all other species with which it can exchange genes, becomes a gene pool from which desirable combinations can be synthesized by the new techniques now available. The synthesis of new amphidiploids, the induction of advantageous mutations, and the use of embryo culture to make difficult interspecific crosses possible-all these play a part in modern plant breeding. 
The evaluation and utilization of a wide range of world material needs considerable knowledge of taxonomy and cytology as well as genetics. Further, the study of the evolution and adaptation of cultivated plants is a separate discipline in itself. It was with the object of surveying existing knowledge of the origin and distribution of cultivated plants in South Asia that the Indian Society of Genetics and Plant Breeding, in association with the United Nations Educational, Scientific and Cultural Organization, held a symposium on this subject in Delhi during January 12-15, 1951. The proceedings of the meeting have now been reported in full in the special "Symposium" number of the Indian Journal of Genetics and Plant Breeding (11, No. 1), which has been recently published. In addition to a large number of members of the Indian Society of Genetics and Plant Breeding, the symposium was attended by representatives of other scientific institutions in India and of Unesco, and by delegates from Ceylon, China, Malaya and Pakistan. Profs. E. Anderson, S. C. Harland and A. Müntzing were invited as "expert consultants".

Altogether, twenty-three papers were read, covering a wide range of crops, including rice, wheat, banana, mango, citrus, sugar-cane, millets, cotton and jute. Much new information was presented, and it was evident that the Asiatic countries are for the most part fully aware of the nature and complexity of modern methodology in plant breeding, though they are only occasionally well enough equipped to solve their special local problems.

The participants of the symposium made a series of recommendations for the betterment of plant breeding in South Asia. These emphasized that plant introductions should be made from areas having similar climatic and environmental conditions. The importance of new introductions of plants from Mexico, Peru and Guatemala was stressed. By means of appropriato national or international organizations, the plant resources of the whole area of South Asia should be surveyed, and plant breeding should be accompanied by fundamental work on cytogenetics and physiology in the various botanical research centres.

S. C. Harland

\section{PACIFIC SCIENCE ASSOCIATION}

$T$

HE Pacific Science Association, which was 1 founded in 1920 and has consistently sought to promote scientific progress in the Pacific, includes as integral parts of its organization the Pacific Science Council, a number of standing committees and the Pacific Science Congresses, of which the eighth is to be held in the Philippines in 1953. The secretariat of the Council has now issued a first report of the Association*, which describes in detail the organization of the Association and its constituent bodies, and its relations with the South Pacific Commission and with the Pacific Science Board of the United States National Research Council; the report also sketches the activities of the Association and its Congresses during the past thirty years as well as, more particularly, the activities of the secretariat during 1950.

Since the constitution and by-laws of the Association are included with the resolutions for research in

* Bernice P. Bishop Museum. Special Publication 41 : Report on the Pacific Science Association. Prepared by the Secreteriat of the Council, 1951.) the Pacific passed at the first seven Congresses and with particulars of the organizing committees and projects appointed for the eighth Congress in 1953, the report constitutes a unique reference handbook on research in this area. The resolutions of previous Congresses are arranged under geology, geodesy and geophysics, volcanology and seismology, meteorology, oceanography, zoology, entomology, botany, conservation, agriculture and soils, forestry, anthropology and social studies, and health and nutrition; they are cross-referenced and are preceded by short accounts indicating the general lines of work and progress made.

'The idea of the Pacific Science Association had its origins at meetings earlier than the Pan-Pacific Scientific Congress at Honolulu in August 1920 - for example, the Australian meeting of the British Association in 1914, the symposium on Pacific Exploration at the 1916 meeting of the United States National Academy of Sciences, and the conference on international relations at the science-centennial anniversary of the University of California in 1918and the Pacific Scientific Institution at Hawaii was incorporated in 1907. The Honolulu Congress included sessions on anthropology, biological sciences, geography, geology, seismology and volcanology, and it was resolved that similar conferences should be held at intervals of not more than three years. At the second congress in Melbourne and Sydney in 1923, when the attendance of 101 from nine territories increased to $\mathbf{1 , 3 8 9}$ from twenty-one territories, and other sections were added, further steps were taken towards a permanent organization with its own central scientific bureau or secretariat, and the present constitution and by-laws were adopted at the third Congress in Tokyo in 1926, when the prefix "Pan" was dropped from the title.

The constitution provides for a Council of ten to fifteen members and a number of standing committees to study the more important problems of common interest and to report on their work at the succeeding congresses. There are at present seventeen such committees; but a permanent secretariat was not established until the seventh Congress, in New Zealand in 1949, and in this Congress the United Nations Educational, Scientific and Cultural Organization played an important part, contributing a subvention of 20 million dollars to enable scientific workers from war-devastated countries in Europe and Asia to be invited. Members from Trust Territories in the Pacific were also represented. Other Congresses were held at Java in 1929, in Vancouver and Victoria, British Columbia, 1933, and in California during July-August 1939.

The seventh Congress, originally scheduled for 1943 in the Philippines, was postponed until 1949, and at this meeting Honolulu was selected as the international headquarters, the secretariat being officially established there in the Bernice P. Bishop Museum on March 20, 1950. The secretariat is assembling a file on current research in the Pacific and has commenced a summary file of scientific expeditions into the Pacific, particularly since 1900, in which the co-operation of scientific workers is invited. The secretariat has also initiated the formation of a Conservation Council for Hawaii and is seeking to establish an epidemiological information centre for the Pacific. It has also handled several specific inquiries from men of science and is issuing an Information Bulletin at six-weekly intervals, which is distributed free on request. 